\title{
Inflammation-associated gene polymorphisms and clinical variables in the incidence and progression of retinopathy of prematurity
}

\author{
DAWID SZPECHT ${ }^{l}$, ANNA CHMIELARZ-CZARNOCINSKA ${ }^{2}$, JANUSZ GADZINOWSKI ${ }^{1}$, \\ AGNIESZKA SEREMAK-MROZIKIEWICZ3', GRAŻYNA KURZAWIŃSKA ${ }^{3}$, MARTA \\ SZYMANKIEWICZ' ${ }^{1}$ KRZYSZTOF DREWS ${ }^{3}$, ANNA GOTZ-WIECCKOWSKA ${ }^{2}$ \\ ${ }^{1}$ Chair and Department of Neonatology, Poznan University of Medical Sciences, Poznan, Poland \\ ${ }^{2}$ Chair and Department of Ophthalmology, Poznan University of Medical Sciences, Poznan, Poland \\ ${ }^{3}$ Department of Perinatology and Women's Diseases, Poznan University of Medical Sciences, Poznan, Poland
}

\begin{abstract}
Introduction: A growing body of evidence shows that genetics plays a vital role in the development and progression of retinopathy of prematurity $(R O P)$. Perinatal inflammation is also considered an important risk factor of ROP. Therefore, understanding the interplay of genetics and susceptibility to inflammation might shed light on the pathogenesis of ROP and make its screening and treatment more effective in preventing visual impairment in premature infants.

Material and methods: This study investigated the correlation of inflammation-associated gene polymorphisms: IL-1 $\beta+3953 C>T, I L-1 R N$ VNTR 86 bp, IL-6 - $174 G>C, I L-6-596$ G $>A$, and TNF- $\alpha$ $-308 G>A$ as well as demographic and clinical characteristics of ROP in preterm infants $(n=90)$.

Results: Our results demonstrate that IL-1RN rs2234663 1/1 genotype prevails in infants with $R O P$ that regresses without intervention, when compared to those requiring laser photocoagulation/ anti-VEGF injection $(p=0.031)$. Genotype $2 / 2$ of IL-1RN occurs more frequently in children with severe $R O P(28.6 \%)$ than in the group in which ROP regressed spontaneously $(4.0 \%)$. The analysis revealed also differences between the genotypes of IL-IRN in ROP patients with intrauterine infection and in patients who had ROP without intrauterine infection; however, this was not statistically significant. Other studied polymorphisms were not associated with ROP development or its progression.

Conclusions: These results suggest that different genotypes of IL-IRN might have an impact on the course of ROP. Genotype 2/2 of IL-1RN gene may predispose to ROP progression.
\end{abstract}

Key words: inflammation, polymorphism, laser photocoagulation, retinopathy of prematurity (ROP), ranibizumab injection.

(Cent Eur J Immunol 2020; 45 (3): 283-293)

\section{Introduction}

Despite screening guidelines based on the latest scientific reports and constantly perfected treatment procedures, retinopathy of prematurity (ROP) still ranks as one of the most significant causes of blindness in children throughout the world $[1,2]$. Due to modern advances in neonatal care in developed countries, which enable the survival of extremely immature infants, ROP is becoming an increasing clinical and societal problem of contemporary paediatric health care. Regular examinations of children from high-risk groups permit early detection and treatment of progressive ROP, reducing future visual impairment. However, some children who develop ROP will suffer from retinal detachment despite screening and timely treatment.
On the other hand, only about $30-40 \%$ of screened infants $(<1500 \mathrm{~g})$ will develop ROP [3, 4], and an even fewer (1.5-9.5\%) will require ophthalmological intervention $[3,5,6]$. In the remaining cases, ROP will never occur or will be self-limiting; but these children undergo numerous stressful examinations due to the existing guidelines. Hence, the incentive for a better understanding of the determinants of ROP, which would not only diminish the risk of visual impairment in the most susceptible infants but also limit the number of unnecessary check-ups.

Large multicentre studies have shown that low birth weight (BW), low gestational age (GA), and prolonged oxygen supplementation are the most important predictive factors of ROP development [7-10]. A variety of existing

Correspondence: Dawid Szpecht, MD, Asst. Prof., Chair and Department of Neonatology, Poznan University of Medical Sciences,

33 Polna St., 60-535 Poznan, Poland, e-mail: dawid.szpecht@poczta.fm

Submitted: 29.03.2018; Accepted: 2.10.2018 
research enumerates additional potential risk factors such as low Apgar score, vaginal mode of delivery, intraventricular haemorrhage (IVH), necrotising enterocolitis (NEC), and bronchopulmonary dysplasia (BPD) [3, 11-14]. Furthermore, molecular studies have discovered the significant role of vascular endothelial growth factor (VEGF) in the pathogenesis of ROP [15]. However, despite these findings, ROP takes an unpredictable course in some infants, which might be due to their genetic makeup. Recent studies also show growing support for a link between both antenatal and neonatal exposure to inflammation and increased risk of ROP $[16,17]$. Therefore, the need for closer investigation of the inflammation-associated genetic basis of this condition, which would help to identify infants predisposed to the disease itself and, even more importantly, its progression to the stages at which treatment is necessary and the risk of visual impairment is high.

The aim of this study was to evaluate the possible relationship between four single nucleotide polymorphisms (SNPs) of inflammation-linked genes encoding for interleukin $1(I L-1 \beta+3953 \mathrm{C}>\mathrm{T})$, interleukin $6(I L-6-174 \mathrm{G}>\mathrm{C}$ and $I L-6-596 \mathrm{G}>\mathrm{A})$, and tumour necrosis factor $\alpha(T N F-\alpha$ $-308 \mathrm{G}>\mathrm{A}$ ) and variable number tandem repeat (VNTR) polymorphisms of interleukin-1 receptor antagonist $(I L$ $I R N$ VNTR $86 \mathrm{bp}$ ) and the occurrence of ROP in a population of preterm infants. The demographic data and clinical characteristics of the study group were also reviewed.

\section{Material and methods}

The study followed the tenets of the Declaration of Helsinki and was approved by the Bioethics Committee of Poznan University of Medical Sciences (66/14 and 799/16).

\section{Study population}

Between $1^{\text {st }}$ March 2014 and $11^{\text {th }}$ June 2016, 402 premature infants were born from $22+0$ to $33+0$ weeks of gestation and admitted to the Neonatal Intensive Care Unit at Poznan University of Medical Sciences. Of these infants, $90(22.4 \%)$ were found eligible for the study. Other infants were excluded due to an increased risk of complications of prematurity by one of the following factors: birth from multiple pregnancies, birth from pregnancies complicated by death of one of the foetuses, presence of chromosomal abnormalities, presence of inherited errors of metabolism, or death before 40 weeks of postmenstrual age. Also, children diagnosed with congenital infections from TORCH complex organisms (toxoplasmosis, other, rubella, cytomegalovirus, herpes) were excluded due to the potentially harmful effect of these infections on the eye such as chorioretinal scarring or active chorioretinitis. All infants and their parents were Caucasian, which ensured a degree of homogeneity of the study population.
We included in the study group only patients who either underwent the series of retinal screening examinations and in whom further possibility of ROP development was minimal due to postmenstrual age of $\geq 40$ weeks (when vascularisation of the retina should be complete or almost complete) or those who developed ROP. The children in whom ROP occurred were examined until either total regression of the condition or they received treatment and remained in systematic follow-up with our outpatient clinic after discharge from the hospital.

\section{Retinopathy of prematurity diagnosis}

Due to gestational age of less than $33+0$ weeks all enrolled infants met the criteria of the National Specialist Team in Paediatrics and School Medicine and Polish Ophthalmological Society for ROP screening $(\leq 33$ weeks of postmenstrual age, $\leq 1800 \mathrm{~g}$ of birth weight, or on the request of neonatology specialist due to high risk of ROP) and underwent a series of ophthalmological examinations. The first examination was undertaken at four weeks of chronological age. Further examination was conducted depending on the condition of the eyes, every 7-10 days. Examinations continued until retinal vascularisation reached zone III, when the risk of a serious adverse outcome of ROP is minimal [18] or when the patient showed signs of ROP regression on at least two examinations. All examinations were performed by one of three paediatric ophthalmologists trained in the ROP screening procedure. The advancement of the disease, e.g. stage, zone, and the presence of plus disease and other meaningful changes, were assessed and documented according to International Classification of Retinopathy of Prematurity (ICROP) [19].

\section{Retinopathy of prematurity treatment}

The treatment criteria were based on the Early Treatment for Retinopathy of Prematurity guidelines [9], which were maintained by the American Academy of Paediatrics policy statement in 2013 [20]. Treatment was administered in the eyes of the patients with any stage of ROP in zone I with plus disease; zone I, stage 3 ROP without plus disease; or zone II, stage 2 or 3 ROP with plus disease. In other cases, a wait-and-watch approach was applied. Eyes were systematically examined and treated if progression occurred.

The decision on the treatment method was based on the most recent reliable scientific reports due to a lack of conclusive international guidelines. Laser photocoagulation of the peripheral avascular retina is the treatment standard in our centre. Yet, in severe zone I ROP we used intravitreal injection of ranibizumab, the anti-VEGF antibody, as an off-label therapy. The latest reports confirm the effectiveness of anti-VEGF monotherapy compared to laser ablation for zone I in infants with stage 3+ ROP [21]. However, this method is used with caution due to concerns 
regarding the short- and long-term safety of anti-VEGF treatment to ocular and neurologic development. Both procedures were performed after obtaining written, informed consent from the parents or legal guardians of the patients.

\section{Studied polymorphisms}

The selection criteria for candidate genes was based on their potential involvement in the pathogenesis of ROP. The products of the selected genes are the key mediators in the inflammatory process. Intrauterine infection is the most frequent cause of preterm birth, which accounts for around $40 \%$ of all cases [22]. It may cause foetal infection and inflammation, thus inducing the inflammatory response in both foetuses and newborns. Microorganisms and their toxins induce foetal production of IL-6 and other inflammatory markers such as IL- 1 and TNF- $\alpha$. They may distort retinal vascularisation leading to ROP development. Due to the significant role of Il-1, Il-6, and TNF- $\alpha$ in the process of inflammation and their possible link with ROP development, we concluded that the chosen polymorphisms may play a role in the pathogenesis of ROP.

We studied four SNPs: $I L-1 \beta+3953 \mathrm{C}>\mathrm{T}, I L-6-174$ $\mathrm{G}>\mathrm{C}, I L-6-596 \mathrm{G}>\mathrm{A}$, and $T N F-\alpha-308 \mathrm{G}>\mathrm{A}$ and a variable number of tandem repeat (VNTR) polymorphisms $I L-1 R N$ VNTR 86 bp. Their characteristics are shown in Table 1.

A $0.5 \mathrm{ml}$ sample of blood was taken directly after the delivery and banked. Genomic DNA was extracted from blood leukocytes using QIAamp DNA Blood Mini Kit (QIAGEN Inc., Germany). Genotyping was performed using Restriction Fragment Length Polymorphism analysis of PCR-amplified fragments (PCR-RFLP) and gel electro- phoresis. Written, informed consent for blood collection and genetic testing was obtained from the parents or legal guardians of the patients.

For detection of the $I L-1 \beta+3953 C>$ T mutation, PCR was amplified with starters: F 5 -gTTgTC ATC Aga CTT TgA CC-3`; R 5`-TTC AgT TCA TAT ggA CCA gA-3` (PCR product $251 \mathrm{bp}$ long) and hydrolysed with TaqI restriction enzyme (Thermo Scientific). The following genotypes were obtained: CC (137, 114 bp), CT (251, 137, $114 \mathrm{bp}$ ), and TT (251 bp). Replacement of cytosine with thymine leads to the occurrence of a rarer allele 2, which is connected with higher production of IL- $1 \beta$.

For detection of the $I L-6-174 G>C$ mutation, PCR was amplified using the starters: F 5-ACA TgC CAA gTgCTgAgT CA-3', R 5`AAT CTT TgTTggAgggTg Ag-3' (PCR product 214 bp long) and hydrolysed with LweI restriction enzyme (Thermo Scientific). The following genotypes were obtained: GG (114, $100 \mathrm{bp}), \mathrm{GC}(214,114,100$ bp), and CC (214 bp). The following starters were used for detection of the $I L-6-596 G>A$ mutation: F 5 -ggAgTC ACA CAC TCC ACC Tg-3` and R 5`-AAgCAg AAC CAC TCT TCC TTT ACT T-3'. The PCR products (420 bp long) were hydrolysed with BseGI (BtsCI) restriction enzyme (Thermo Scientific) and yielded the following genotypes: GG (420 bp), GA (420, 354, 66 bp), and AA (354, 66 bp). In our research we analysed IL-6 -174G $>C$ and $-596 \mathrm{G}>\mathrm{A}$ polymorphisms. Both homozygotes $\mathrm{CC}$ of polymorphism IL-6 -174G $>$ C and AA of polymorphism IL-6 -596G $>$ A result in decreased production of IL-6.

The $T N F-\alpha-308 G>A$ polymorphism was detected using the following starters: $5^{-}$-AAA TggAgg CAA Tag gTTTTgAggggCTTg-3’ and 5 -TAC CCC TCA CAC

Table 1. Description of the five studied polymorphisms in $I L-1, I L-6, I L-1 R N$, and $T N F-\alpha$ genes

\begin{tabular}{|c|c|c|c|c|}
\hline Gene symbol & Polymorphism & Sequence of primers & Restriction enzyme & Products \\
\hline IL-1 $\beta$ (rs1143634) & $+3953 \mathrm{C}>\mathrm{T}$ & $\begin{array}{l}\text { F } 5 \text { `-gTT gTC ATC Aga CTT TgA CC-3 } \\
\text { R } 5 \text {-TTC AgT TCA TAT ggA CCA gA-3` }\end{array}$ & $\begin{array}{c}\text { TaqI } \\
\text { (Thermo Scientific) }\end{array}$ & $\begin{array}{l}\text { CC137, 114 bp } \\
\text { CT251,137,114 bp } \\
\text { TT251 bp }\end{array}$ \\
\hline IL-1RN (rs2234663) & VNTR 86 bp & $\begin{array}{c}\text { F 5`CTC AgC AAC ACT CCT AT-3` } \\
\text { R 5`-TCC Tgg TCT gCA ggT AA-3 }\end{array}$ & & $\begin{array}{l}\text { IL1RN*0 } 154 \text { bp } \\
\text { IL1RN*1 } 410 p z \text { bp } \\
\text { IL1RN*2 } 240 \mathrm{bp} \\
\text { IL1RN*3 } 500 \mathrm{bp} \\
\text { IL1RN*4 } 325 \mathrm{bp} \\
\text { IL1RN*5 } 595 \mathrm{bp}\end{array}$ \\
\hline $\begin{array}{l}\text { IL-6 } \\
\text { (rs1800795) }\end{array}$ & $-174 \mathrm{G}>\mathrm{C}$ & $\begin{array}{c}\text { F 5`-ACA TgC CAA gTg CTg AgT CA-3 } \\
\text { R 5`-AAT CTT TgT Tgg Agg gTg Ag-3 }\end{array}$ & $\begin{array}{c}\text { LweI } \\
\text { (Thermo Scientific) }\end{array}$ & $\begin{array}{l}\text { GG114,100 bp } \\
\text { GC214,114,100 bp } \\
\text { CC } 214 \text { bp }\end{array}$ \\
\hline $\begin{array}{l}\text { IL-6 } \\
\text { (rs1800797) }\end{array}$ & $-596 \mathrm{G}>\mathrm{A}$ & $\begin{array}{c}\text { F 5 -ggA gTC ACA CAC TCC ACC Tg-3 } \\
\text { R 5`-AAg CAg AAC CAC TCT TCC TTT } \\
\text { ACT T-3 }\end{array}$ & $\begin{array}{l}\text { BseGI(BtsCI) } \\
\text { (Thermo Scientific) }\end{array}$ & $\begin{array}{c}\text { GG420 bp GA420,354,66 } \\
\text { bp } \\
\text { AA354, } 66 \text { bp }\end{array}$ \\
\hline TNF- $\alpha($ rs1800629) & $-308 \mathrm{G}>\mathrm{A}$ & $\begin{array}{l}\text { 5`-AAA Tgg Agg CAA Tag gTT TTg Agg } \\
\text { ggC TTg } \\
\text { 5 - TAC CCC TCA CAC TCC CCA TCC TCC } \\
\text { CTg ATC }\end{array}$ & FaqI (BsmFI) & $\begin{array}{c}\text { GG86,45 bp } \\
\text { GA131,86,45 bp } \\
\text { AA131 bp }\end{array}$ \\
\hline
\end{tabular}


TCC CCA TCC TCC CTg ATC-3' (TIBMolBiol). The PCR product (131 bp) was hydrolysed with FaqI (BsmFI) restriction enzyme, and the following genotypes were found: $\mathrm{GG}(86,45 \mathrm{bp}), \mathrm{GA}(131,86,45 \mathrm{bp})$, and AA (131 bp). The consequence of replacement of guanine by adenosine in this polymorphism results in the loss of binding place for AP-2 transcription factor.

The 86 bp variable number tandem repeat polymorphism of IL-1RN VNTR $86 b p$ was analysed with PCR using the following starters: F 5 -CTC AgC AAC ACT CCT AT-3` and R 5`-TCC Tgg TCT gCAggT AA-3` (TiBMolBiol). It was possible to obtain products with lengths of: 154 bp (IL1RN*0), 410 bp (IL1RN*1), 240 bp (IL$1 \mathrm{RN} * 2), 500 \mathrm{bp}(\mathrm{IL} 1 \mathrm{RN} * 3), 325 \mathrm{bp}$ (IL1RN*4), and 595 bp (IL1RN*5). The main role is played by the number of repeats of 86-bp sequences within intron 2 of the human IL-1 receptor antagonist gene. The number of repeats is of functional significance because these repeats contain binding sites for transcription factors.

\section{Statistical analysis}

The following factors that may associate with the development of ROP were studied: gender, gestational age (GA, weeks), birth weight (BW, grams), small for gestational age (SGA, defined as birth weight under third percentile), Apgar score (in first and fifth minute), type of delivery (vaginal birth vs. caesarean section), birth asphyxia (defined as Apgar score less than 6 at 10 minutes and $\mathrm{pH}<7.0$ or blood base excess [BE] $<-15 \mathrm{mmol} / 1$ in cord blood), intrauterine infection (defined as positive culture in sterile originally accompanied by clinical symptoms or pneumonia developed in 48 hours after the birth), late onset infection (defined as pneumonia, sepsis or infection of urinary tract), type of ventilation support (non-invasive vs. conventional), and complications of prematurity (bronchopulmonary dysplasia [BPD], intraventricular haemorrhage $[\mathrm{IVH}]$, necrotizing enterocolitis [NEC]). The results are presented as percentages of categorical variables or median (range) for non-normally distributed continuous variables as tested by the Shapiro-Wilk test. A p-value of less than 0.05 was considered significant. The Fisher exact probability test, the $\chi^{2}$ test, Fisher-Freeman-Halton exact test, and $\chi^{2}$ test with Yates correction were used to evaluate association between ROP and categorical variables. Differences in non-normally distributed continuous variables were compared by the $U$ Mann-Whitney test. Logistic regression analysis was used to estimate odds ratios (OR) and confidence intervals (CI) of $95 \%$. Statistical analysis was performed using CytelStudio version 10.0, created on January 16, 2013 (CytelStudio Software Corporation, Cambridge, Massachusetts, United States), and Statistica version 10, 2011 (Stat Soft, Inc., Tulsa, Oklahoma, United States). The expected genotype frequencies were calculated from allele frequencies with the Hardy-Weinberg equilibrium.

\section{Results}

The median gestational age of the 90 enrolled children was $29 \pm 2$ weeks (range 22-33), and the median birth weight was $1120 \pm 366$ grams (range $510-2340$ ). We found that 39 preterm infants, 20 males and 19 females ( 72 eyes; in six infants ROP was found only in a single eye), developed ROP in our study population. Treatment-requiring ROP was present in 14 infants (16\% of total, $36 \%$ of ROP cases), 28 eyes (39\% of eyes with ROP), and was managed with laser photocoagulation (11 children, 22 eyes), ranibizumab injection (two children, four eyes), or a combination of these two treatment methods (one child, two eyes), as clinically indicated. The clinical and demographic data of enrolled infants and the comparison among the groups of children with vs. without ROP and non-treatment-requiring vs. treatment-requiring ROP patients are shown in Table 2.

The following frequencies of genotypes of $I L 1 R N$ were found in infants with ROP without treatment: $1 / 1-64.0 \%$, $1 / 2-32.0 \%, 1 / 3-0 \%, 2 / 2-4.0 \%, 2 / 3-0 \%$. Corresponding frequencies in patients treated with laser/ranibizumab were: $1 / 1-42.8 \%, 1 / 2-28.6 \%, 1 / 3-0 \%, 2 / 2-28.6 \%$, $2 / 3-0 \%(p=0.086)$. There was a statistically significant higher prevalence of genotype $2 / 2$ of $I L-1 R N$ ( $p=0.031$; OR 10.67 [0.984-115.7]) polymorphism in infants with ROP that required treatment with laser/ranibizumab compared to those without treatment. 2/2 genotype was also found in the only infant from our study population with ROP recurrence, who required a secondary line of treatment. No correlation was found between the occurrence of ROP or necessity of ROP treatment and the following polymorphisms: $I L-1 \beta$ $+3953 \mathrm{C}>\mathrm{T}, I L-6-174 \mathrm{G}>\mathrm{C}, I L-6-596 \mathrm{G}>\mathrm{A}$, and $T N F-\alpha$ $-308 \mathrm{G}>\mathrm{A}$. However, for both IL-6 polymorphisms the deviation from Hardy-Weinberg equilibrium was observed for ROP patients. The deviation was also present for $I L-6-596$ $\mathrm{G}>\mathrm{A}$ polymorphism for ROP patients not requiring treatment. Genotype and allele distributions of studied polymorphisms and the analysis for Hardy-Weinberg equilibrium in infants without and with ROP, and without and with ROP treatment, are shown in Table 3.

The analysis revealed differences between the genotypes of $I L-I R N$ in the patients with ROP and intrauterine infection and the patients with ROP and without intrauterine infection. The following frequencies of genotypes of $I L-1 R N$ were found in infants with ROP and intrauterine infection: $1 / 1-45.4 \%, 1 / 2-36.4 \%, 1 / 3-0 \%, 2 / 2$ $-18.2 \%, 2 / 3-0 \%$, and for patients with ROP and without intrauterine infection: $1 / 1-70.5 \%, 1 / 2-23.5 \%, 1 / 3-0 \%$, $2 / 2-6.0 \%, 2 / 3-0 \%$. Notably, $2 / 2$ genotype of $I L-1 R N$ was more prevalent in infected vs. non-infected patients with ROP, but the difference was not statistically significant. We did not observe any association between intrauterine infection in patients with ROP and other studied polymorphisms. For both IL-6 polymorphisms the devia- 
Table 2. Demographic and clinical characteristic of enrolled infants

\begin{tabular}{|c|c|c|c|c|c|c|}
\hline Characteristic & $\begin{array}{c}\text { No ROP } \\
(n=51)\end{array}$ & $\begin{array}{c}\text { ROP } \\
(n=39)\end{array}$ & $p$ & $\begin{array}{c}\text { Non-treatment- } \\
\text { requiring ROP } \\
\quad(n=25)\end{array}$ & $\begin{array}{c}\text { Treatment-requiring } \\
\text { ROP } \\
(n=14)\end{array}$ & $p$ \\
\hline Female, $n(\%)$ & $25(49.0)$ & $19(48.7)$ & $0.977^{\mathrm{a}}$ & $12(48.0)$ & $7(50.0)$ & $0.831^{\mathrm{c}}$ \\
\hline Gestational age (weeks) & & & $<0.0001^{\mathrm{a}}$ & & & $0.218^{\mathrm{e}}$ \\
\hline median and range & $30(26-33)$ & $26(22-31)$ & & $27(23-31)$ & $25(22-30)$ & \\
\hline $24-28(n, \%)$ & $14(27.5)$ & $31(79.5)$ & & $18(72.0)$ & $13(92.8)$ & \\
\hline $29-32(n, \%)$ & $37(72.5)$ & $8(20.5)$ & & $7(28.0)$ & $1(7.0)$ & \\
\hline Birth weight (gram) & & & $<0.0001^{\mathrm{b}}$ & & & $0.077^{\mathrm{a}}$ \\
\hline median and range & $1345(790-2340)$ & $860(510-1500)$ & & $930(610-1500)$ & $810(510-1300)$ & \\
\hline$<750$ & $0(0.0)$ & $9(23.1)$ & & $3(12.0)$ & $6(42.8)$ & \\
\hline $750-1000$ & $9(17.6)$ & $16(41.0)$ & & $11(44.0)$ & $5(35.7)$ & \\
\hline$>1000$ & $42(82.3)$ & $14(35.9)$ & & $11(44.0)$ & $3(21.4)$ & \\
\hline \multicolumn{7}{|l|}{ Apgar score (median and range) } \\
\hline $1^{\text {st }}$ minute & $6(1-10)$ & $4(1-9)$ & $0.0001^{\mathrm{d}}$ & $5(1-9)$ & $4(1-6)$ & $0.656^{\mathrm{d}}$ \\
\hline $5^{\text {th }}$ minute & $8(5-10)$ & $7(1-9)$ & $0.0002^{\mathrm{d}}$ & $7(1-9)$ & $7(4-9)$ & $0.226^{\mathrm{d}}$ \\
\hline Mode of delivery, $n(\%)$ & & & $0.578^{\mathrm{a}}$ & & & $1.000^{\mathrm{e}}$ \\
\hline Vaginal & $18(35.3)$ & $16(41.0)$ & & $10(40.0)$ & $6(42.8)$ & \\
\hline Caesarean section & $33(64.7)$ & $23(59.0)$ & & $15(60.0)$ & $8(57.1)$ & \\
\hline $\begin{array}{l}\text { Mechanical ventilation (days) } \\
\text { median and range }\end{array}$ & $8(1-53)$ & $54(3-146)$ & $<0.0001^{\mathrm{d}}$ & $44(3-101)$ & $80(3-146)$ & $0.005^{\mathrm{d}}$ \\
\hline Asphyxia $(n, \%)$ & $3(5.9)$ & $5(12.8)$ & $0.440^{c}$ & $2(8.0)$ & $3(21.4)$ & $0.329^{\mathrm{e}}$ \\
\hline Intrauterine infection $(n, \%)$ & $24(47.0)$ & $22(56.4)$ & $0.379^{\mathrm{a}}$ & $14(56.0)$ & $8(57.1)$ & $0.789^{\mathrm{c}}$ \\
\hline Late-onset infection $(n, \%)$ & $6(11.7)$ & $6(15.4)$ & $0.851^{\mathrm{b}}$ & $4(16.0)$ & $2(14.3)$ & $1.000^{\mathrm{e}}$ \\
\hline $\mathrm{IVH}(n, \%)$ & $11(21.6)$ & $23(59.0)$ & $0.0003^{\mathrm{a}}$ & $11(44.0)$ & $12(85.7)$ & $0.028^{\mathrm{c}}$ \\
\hline $\operatorname{BPD}(n, \%)$ & $6(11.7)$ & $20(51.3)$ & $<0.0001 \mathrm{a}$ & $11(44.0)$ & $9(64.3)$ & $0.378^{\mathrm{c}}$ \\
\hline $\operatorname{NEC}(n, \%)$ & $8(15.7)$ & $9(23.1)$ & $0.538 \mathrm{c}$ & $4(16.0)$ & $5(35.7)$ & $0.238^{\mathrm{e}}$ \\
\hline
\end{tabular}

${ }^{a} \chi^{2}$ test, ${ }^{b}$ Fisher Freeman Halton test, ${ }^{c} \chi^{2}$ test with Yate's correction, ${ }^{d}$ Mann-Whitney test, ${ }^{e}$ Fisher exact test, IVH - intraventricular haemorrhage, BPDbronchopulmonary dysplasia, NEC-necrotising enterocolitis

tion from Hardy-Weinberg equilibrium was observed for patients without intrauterine infection and for ROP patients with intrauterine infection. Genotype distributions of studied polymorphisms and the analysis for Hardy-Weinberg equilibrium in infants without and with intrauterine infection, in ROP patients with intrauterine infection, and in patients that have ROP without intrauterine infection are shown in Table 4.

\section{Discussion}

As far as clinical characteristics of the study group are concerned, our data is in accordance with previous studies, in which the most important risk factors for ROP development were low BW and GA at birth as well as exposure to supplemental oxygen [23, 24].

The statistical analysis of our patients' characteristics also indicated other variables that can be associated with ROP de- velopment, including: lower median Apgar score in the first and fifth minute, prolonged mechanical ventilation, IVH, and BPD. These findings are largely consistent with previously-published research involving ROP risk factors [3, 11-14]. The important clinically relevant finding was that the only two environmental variables that statistically significantly correlated with a progression to threshold ROP were IVH and the excessive use of oxygen; this has also been reported in previous studies [3]. However, not all infants with prolonged ventilation develop ROP and even fewer require treatment. It remains uncertain whether IVH has an impact on ROP progression or if it co-exists with ROP. Despite extensive research, it is still not well understood why ROP progresses to severe stages in some infants while in others, despite similar clinical conditions, it regresses spontaneously.

We hypothesised that a plausible explanation might be the interplay of the genetic factors and predisposition to 
Table 3. Genotype distribution of studied polymorphisms and the analysis for Hardy-Weinberg equilibrium in infants without and with retinopathy of prematurity (ROP), and without and with ROP treatment

\begin{tabular}{|c|c|c|c|c|c|c|c|c|c|}
\hline $\begin{array}{l}\text { Gene } \\
\text { symbol } \\
\text { db SNP }\end{array}$ & 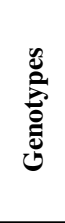 & $\begin{array}{c}\text { No ROP } \\
(n=51) \\
\text { observed/ } \\
\text { (expected) }\end{array}$ & $\begin{array}{c}\text { ROP } \\
(n=39) \\
\text { observed/ } \\
\text { (expected) }\end{array}$ & $p$ & $\begin{array}{c}\text { OR } 95 \% \mathrm{CI} \\
p\end{array}$ & $\begin{array}{c}\text { Non- } \\
\text { treatment- } \\
\text { requiring ROP } \\
(\boldsymbol{n}=\mathbf{2 5}) \\
\text { observed/ } \\
\text { (expected) }\end{array}$ & $\begin{array}{c}\text { Treatment- } \\
\text { requiring } \\
\text { ROP } \\
(n=14) \\
\text { observed/ } \\
\text { (expected) }\end{array}$ & $p$ & $\begin{array}{c}\text { OR } 95 \% \text { CI } \\
p\end{array}$ \\
\hline \multirow{3}{*}{$\begin{array}{l}\mathrm{IL}-1 \beta \\
+3953 \mathrm{C}>\mathrm{T} \\
\mathrm{rs} 1143634\end{array}$} & $\mathrm{CC}$ & $30(28.3)$ & $23(23.1)$ & $0.721^{\mathrm{a}}$ & Reference & $12(12.3)$ & $11(11.2)$ & $0.225^{\mathrm{b}}$ & Reference \\
\hline & $\mathrm{CT}$ & $16(19.4)$ & $14(13.8)$ & & $\begin{array}{c}1.141 \\
(0.420-3.08) \\
0.952\end{array}$ & $11(10.5)$ & $3(2.7)$ & & $\begin{array}{c}0.298 \\
(0.043-1.606) \\
0.207\end{array}$ \\
\hline & $\mathrm{TT}$ & $5(3.3)$ & $2(2.1)$ & & $\begin{array}{c}0.522 \\
(0.046-3.585) \\
0.749\end{array}$ & $2(2.3)$ & $0(0.2)$ & & $\begin{array}{c}0.000 \\
(0.000-6.754) \\
0.607\end{array}$ \\
\hline HWE $p$ & & 0.214 & 0.945 & & & 0.812 & 0.653 & & \\
\hline Allele C & & 76 & 60 & $0.709^{\mathrm{a}}$ & Reference & 35 & 25 & $0.097^{\mathrm{c}}$ & Reference \\
\hline Allele $\mathrm{T}$ & & 26 & 18 & & $\begin{array}{c}0.877 \\
(0.412-1.842) \\
0.846\end{array}$ & 15 & 3 & & $\begin{array}{c}0.280 \\
(0.048-1.160) \\
0.089\end{array}$ \\
\hline \multirow{5}{*}{$\begin{array}{l}\text { IL-1RN } \\
86 \text { BP VNTR } \\
\text { rs } 2234663 \\
\end{array}$} & $1 / 1$ & $24(22.7)$ & $22(20.1)$ & $0.689^{b}$ & Reference & $16(16)$ & $6(4.6)$ & $0.086^{\mathrm{b}}$ & Reference \\
\hline & $1 / 2$ & 18 (20.6) & $12(15.8)$ & & $\begin{array}{c}0.727 \\
(0.257-2.032) \\
0.665\end{array}$ & $8(8)$ & $4(6.9)$ & & $\begin{array}{c}1.333 \\
(0.211-7.670) \\
1.000\end{array}$ \\
\hline & $1 / 3$ & 2 & 0 & & $\begin{array}{c}0.000 \\
(0.000-6.272) \\
0.576\end{array}$ & 0 & 0 & & - \\
\hline & $2 / 2$ & $6(4.7)$ & $5(3.1)$ & & $\begin{array}{c}1.309 \\
(0.285-6.232) \\
0.948\end{array}$ & $1(1)$ & $4(2.6)$ & & $\begin{array}{c}10.67 \\
(0.984-115.7) \\
0.031\end{array}$ \\
\hline & $2 / 3$ & 1 & 0 & & $\begin{array}{c}0.000 \\
(0.000-44.32) \\
1.000\end{array}$ & 0 & 0 & & - \\
\hline HWE $p$ & & 0.378 & 0.134 & & & 1.000 & 0.119 & & \\
\hline Allele 1 & & 68 & 56 & & Reference & 40 & 16 & & Reference \\
\hline Allele 2 & & 31 & 22 & $0.349^{b}$ & $\begin{array}{c}0.862 \\
(0.425-1.733) \\
0.779 \\
\end{array}$ & 10 & 12 & $0.059^{c}$ & $\begin{array}{c}3.000 \\
(0.957-9.415) \\
0.061\end{array}$ \\
\hline Allele 3 & & 3 & 0 & & $\begin{array}{c}0.000 \\
(0.000-3.051) \\
0.343\end{array}$ & 0 & 0 & & \\
\hline \multirow[t]{3}{*}{$\begin{array}{l}\text { IL-6 } \\
-174 \mathrm{G}>\mathrm{C} \\
\mathrm{rs} 1800795\end{array}$} & GG & $13(13.2)$ & $7(10.8)$ & $0.217^{\mathrm{a}}$ & Reference & $4(6.3)$ & $3(4.6)$ & $0.774^{\mathrm{a}}$ & Reference \\
\hline & GC & $26(25.5)$ & $27(19.4)$ & & $\begin{array}{c}1.929 \\
(0.595-6.619) \\
0.340\end{array}$ & $17(12.5)$ & $10(6.9)$ & & $\begin{array}{c}0784 \\
(0108-6.525) \\
1.000\end{array}$ \\
\hline & $\mathrm{CC}$ & $12(12.3)$ & $5(8.8)$ & & $\begin{array}{c}0.774 \\
(0.150-3.797) \\
0.995\end{array}$ & $4(6.3)$ & $1(2.6)$ & & $\begin{array}{c}0.333 \\
(0.005-7.204) \\
0.849\end{array}$ \\
\hline
\end{tabular}


Table 3. Cont.

\begin{tabular}{|c|c|c|c|c|c|c|c|c|c|}
\hline $\begin{array}{l}\text { Gene } \\
\text { symbol } \\
\text { db SNP }\end{array}$ & 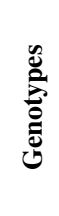 & $\begin{array}{c}\text { No ROP } \\
(n=51) \\
\text { observed/ } \\
\text { (expected) }\end{array}$ & $\begin{array}{c}\text { ROP } \\
(n=39) \\
\text { observed/ } \\
\text { (expected) }\end{array}$ & $p$ & $\begin{array}{c}\text { OR } 95 \% \text { CI } \\
p\end{array}$ & $\begin{array}{c}\text { Non- } \\
\text { treatment- } \\
\text { requiring ROP } \\
(n=25) \\
\text { observed/ } \\
\text { (expected) }\end{array}$ & $\begin{array}{c}\text { Treatment- } \\
\text { requiring } \\
\text { ROP } \\
(n=14) \\
\text { observed/ } \\
\text { (expected) }\end{array}$ & $p$ & $\begin{array}{c}\text { OR } 95 \% \mathrm{CI} \\
p\end{array}$ \\
\hline HWE $p$ & & 0.886 & 0.015 & & & 0.072 & 0.086 & & \\
\hline Allele G & & 52 & 41 & $0.833^{\mathrm{A}}$ & Reference & 25 & 16 & $0.545^{\mathrm{A}}$ & Reference \\
\hline Allele C & & 50 & 37 & & $\begin{array}{c}0.939 \\
(0.499-1.766) \\
0.952\end{array}$ & 25 & 12 & & $\begin{array}{c}0.750 \\
(0.265-2.098) \\
0.713\end{array}$ \\
\hline \multirow[t]{3}{*}{$\begin{array}{l}\text { IL-6 } \\
-596 \mathrm{G}>\mathrm{A} \\
\text { rs } 1800797\end{array}$} & GG & $15(14.3)$ & $7(11.3)$ & $0.053^{\mathrm{a}}$ & Reference & $4(6.8)$ & $3(4.6)$ & $1.000^{\mathrm{a}}$ & Reference \\
\hline & GA & $24(25.4)$ & $28(19.4)$ & & $\begin{array}{c}2.5(0.788-8.428) \\
0.137\end{array}$ & $18(12.4)$ & $10(6.9)$ & & $\begin{array}{c}0.741 \\
(0.102-6.147) \\
1.000\end{array}$ \\
\hline & $\mathrm{AA}$ & $12(11.3)$ & $4(8.3)$ & & $\begin{array}{c}0.714 \\
(0.124-3.685) \\
0.931\end{array}$ & $3(5.8)$ & $1(2.5)$ & & $\begin{array}{c}0.444 \\
(0.006-10.52) \\
1.000\end{array}$ \\
\hline HWE $p$ & & 0.692 & 0.006 & & & 0.027 & 0.086 & & \\
\hline Allele G & & 54 & 42 & $0.904^{\mathrm{A}}$ & Reference & 26 & 16 & $0.0662^{\mathrm{A}}$ & Reference \\
\hline Allele A & & 48 & 36 & & $\begin{array}{c}0.964 \\
(0.512-1.816) \\
1.000\end{array}$ & 24 & 12 & & $\begin{array}{c}0.813 \\
(0.287-0.273) \\
0.843\end{array}$ \\
\hline \multirow[t]{3}{*}{$\begin{array}{l}\text { TNF- } \alpha \\
-308 G>A \\
\text { rs } 1800629\end{array}$} & GG & $40(40.6)$ & 27 (27.9) & $0.341^{\mathrm{a}}$ & Reference & $18(18.5)$ & $9(9.5)$ & $0.723^{a}$ & Reference \\
\hline & GA & $11(9.8)$ & $12(10.2)$ & & $\begin{array}{c}1.616 \\
(0.558-4.684) \\
0.454 \\
\end{array}$ & $7(6)$ & $5(4.1)$ & & $\begin{array}{c}1.429 \\
(0.272-7.06) \\
0.879 \\
\end{array}$ \\
\hline & $\mathrm{AA}$ & $0(0.6)$ & $0(0.9)$ & & - & $0(0.5)$ & $0(0.4)$ & & - \\
\hline HWE $p$ & & 0.388 & 0.256 & & & 0.416 & 0.416 & & \\
\hline Allele G & & 91 & 66 & $0.489^{\mathrm{C}}$ & Reference & 43 & 23 & $0.900^{\mathrm{C}}$ & Reference \\
\hline Allele A & & 11 & 12 & & $\begin{array}{c}1.504 \\
(0.567-4.009) \\
0.488\end{array}$ & 7 & 5 & & $\begin{array}{c}1.335 \\
(0.298-5.517) \\
0.883\end{array}$ \\
\hline
\end{tabular}

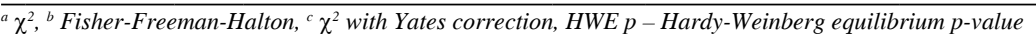

inflammation. Our results indicate the association between intrauterine infection and ROP development, which supports the hypothesis of inflammation-related pathogenetic mechanisms underlying the development of ROP. ELGAN [26] and many other studies support the concept that neonatal sepsis is a risk factor for any stage ROP as well as severe ROP [13, 27]. Also, Sood et al. [28], who studied cytokine levels in extremely low birth weight newborns and showed that some cytokines remained significantly different across ROP groups, concluded that perinatal inflammation may be involved in the pathogenesis of ROP.

Other researchers confirmed a strong genetic predisposition to ROP. Bizzarro et al. [29] analysed 63 monozygotic and 137 dizygotic twin pairs and reached the conclusion that genetic factors accounted for $70.1 \%$ of the variance in liability for retinopathy of prematurity. Similarly, in the Ortega-Molina et al. study [30] heritability of ROP was found to be $72.8 \%$.

We linked these two discoveries and based our research hypothesis on the premise that genetic predisposition may impact the susceptibility to inflammation and in turn might be a key factor that either predisposes or protects against ROP. To date, little attention has been given to polymorphisms of inflammation-associated genes and the development of ROP. To our knowledge, there has been no study investigating $I L-1 R N$ and $I L-6$ gene polymorphism in preterm infants with ROP so far. 
Table 4. Genotype distributions of studied polymorphisms and the analysis for Hardy-Weinberg equilibrium in infants without and with intrauterine infection; with retinopathy of prematurity (ROP) and without and with ROP and with intrauterine infection

\begin{tabular}{|c|c|c|c|c|c|c|c|c|c|}
\hline $\begin{array}{l}\text { Gene symbol } \\
\text { db SNP }\end{array}$ & 递 & $\begin{array}{c}\text { No } \\
\text { infection } \\
(n=44) \\
\text { observed } \\
\text { (expected) }\end{array}$ & $\begin{array}{c}\text { Infection } \\
(n=46) \\
\text { observed } \\
\text { (expected) }\end{array}$ & $p$ & $\begin{array}{c}\text { OR } 95 \% \mathrm{CI} \\
p\end{array}$ & $\begin{array}{c}\text { ROP+ } \\
\text { no infection } \\
(n=17) \\
\text { observed } \\
\text { (expected) }\end{array}$ & $\begin{array}{c}\text { ROP+ } \\
\text { infection } \\
(n=22) \\
\text { observed } \\
\text { (expected) }\end{array}$ & $p$ & $\begin{array}{c}\text { OR } 95 \% \mathrm{CI} \\
p\end{array}$ \\
\hline \multirow{3}{*}{$\begin{array}{l}\mathrm{IL}-1 \beta \\
+3953 \mathrm{C}>\mathrm{T} \\
\mathrm{rs} 1143634\end{array}$} & $\mathrm{CC}$ & $28(27.1)$ & $25(24.4)$ & $0.678^{a}$ & - & $11(9.9)$ & $12(13.2)$ & $0.155^{\mathrm{a}}$ & - \\
\hline & $\mathrm{CT}$ & $13(14.9)$ & $17(18.2)$ & & $\begin{array}{c}1.465 \\
(0.543-3.99) \\
0.547\end{array}$ & $4(6.1)$ & $10(7.7)$ & & $\begin{array}{c}2.292 \\
(0.464-12.79) \\
0.419\end{array}$ \\
\hline & $\mathrm{TT}$ & $3(2)$ & $4(3.4)$ & & $\begin{array}{c}1.493 \\
(0.227-11.13) \\
0.923 \\
\end{array}$ & $2(1)$ & $0(1.1)$ & & $\begin{array}{c}0.000 \\
(0.000-5.709) \\
0.520 \\
\end{array}$ \\
\hline HWE $p$ & & 0.784 & 0.653 & & & 0.154 & 0.168 & & \\
\hline Allele C & & 69 & 67 & $0.384^{\mathrm{a}}$ & Reference & 26 & 34 & $0.393^{\mathrm{c}}$ & Reference \\
\hline Allele T & & 19 & 25 & & $\begin{array}{c}1.355 \\
(0.647-2.862) \\
0.486\end{array}$ & 8 & 18 & & $\begin{array}{c}1.721 \\
(0.593-5.295) \\
0.394\end{array}$ \\
\hline \multirow{5}{*}{$\begin{array}{l}\text { IL-1RN } \\
86 \text { BP VNTR } \\
\text { rs } 2234663\end{array}$} & $1 / 1$ & 24 (23.6) & $22(19.3)$ & $0.249^{b}$ & - & $12(11.5)$ & $10(8.9)$ & $0.342^{\mathrm{b}}$ & - \\
\hline & $1 / 2$ & $15(15.8)$ & $15(20.3)$ & & $\begin{array}{c}1.091 \\
(0.393-3.024) \\
1.000\end{array}$ & $4(4.9)$ & $8(10.2)$ & & $\begin{array}{c}2.4 \\
(0.455-14.0) \\
0.411\end{array}$ \\
\hline & $1 / 3$ & 2 & 0 & & $\begin{array}{c}0.000 \\
(0.000-6.272) \\
0.576\end{array}$ & 0 & 0 & & - \\
\hline & $2 / 2$ & $3(2.6)$ & $8(5.4)$ & & $\begin{array}{c}2.909 \\
(0.589-18.83) \\
0.249\end{array}$ & $1(0.6)$ & $4(2.9)$ & & $\begin{array}{c}4.8 \\
(0.369-255.7) \\
0.372\end{array}$ \\
\hline & $2 / 3$ & 0 & 1 & & - & 0 & 0 & & - \\
\hline HWE $p$ & & 0.758 & 0.079 & & & 0.432 & 0.315 & & \\
\hline Allele 1 & & 65 & 59 & $0.258^{\mathrm{b}}$ & Reference & 28 & 28 & $0.117^{\mathrm{c}}$ & Reference \\
\hline Allele 2 & & 21 & 32 & & $\begin{array}{c}1.679 \\
(0.832-3.418) \\
0.162\end{array}$ & 6 & 16 & & $\begin{array}{c}2.667 \\
(0.826-9.476) \\
0.114\end{array}$ \\
\hline Allele 3 & & 2 & 1 & & $\begin{array}{c}0.551 \\
(0.009-10.88) \\
1.000\end{array}$ & 0 & 0 & & - \\
\hline \multirow{3}{*}{$\begin{array}{l}\text { IL-6 } \\
-174 \mathrm{G}>\mathrm{C} \\
\mathrm{rs} 1800795 \\
\end{array}$} & GG & $9(12.6)$ & $11(11.5)$ & $0.379^{\mathrm{a}}$ & - & $4(5.3)$ & $3(5.5)$ & $0.881^{\mathrm{a}}$ & - \\
\hline & $\mathrm{GC}$ & 29 (21.9) & $24(23)$ & & $\begin{array}{c}0.677 \\
(0.210-2.152) \\
0.632\end{array}$ & $11(8.4)$ & $16(11)$ & & $\begin{array}{c}1.939 \\
(0.263-15.67) \\
0.720\end{array}$ \\
\hline & $\mathrm{CC}$ & $6(9.5)$ & $11(11.5)$ & & $\begin{array}{c}1.5(0.331-7.025) \\
0.794\end{array}$ & $2(3.3)$ & $3(5.5)$ & & $\begin{array}{c}2.000 \\
(0.121-37.87) \\
1.000\end{array}$ \\
\hline
\end{tabular}


Table 4. Cont.

\begin{tabular}{|c|c|c|c|c|c|c|c|c|c|}
\hline $\begin{array}{l}\text { Gene symbol } \\
\text { db SNP }\end{array}$ & 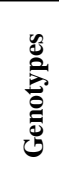 & $\begin{array}{c}\text { No } \\
\text { infection } \\
(n=44) \\
\text { observed } \\
\text { (expected) }\end{array}$ & $\begin{array}{c}\text { Infection } \\
(n=46) \\
\text { observed } \\
\text { (expected) }\end{array}$ & $p$ & $\begin{array}{c}\text { OR } 95 \% \mathrm{CI} \\
p\end{array}$ & $\begin{array}{c}\text { ROP+ } \\
\text { no infection } \\
(n=17) \\
\text { observed } \\
\text { (expected) }\end{array}$ & $\begin{array}{c}\text { ROP+ } \\
\text { infection } \\
(n=22) \\
\text { observed } \\
\text { (expected) }\end{array}$ & $p$ & $\begin{array}{c}\text { OR } 95 \% \mathrm{CI} \\
p\end{array}$ \\
\hline HWE $p$ & & 0.031 & 0.768 & & & 0.198 & 0.033 & & \\
\hline Allele G & & 47 & 46 & $0.647^{\mathrm{a}}$ & Reference & 19 & 22 & $0.606^{\mathrm{a}}$ & Reference \\
\hline Allele C & & 41 & 46 & & $\begin{array}{c}1.146 \\
(0.613-2.146) \\
0.758\end{array}$ & 15 & 22 & & $\begin{array}{c}1.267 \\
(0.470-3.428) \\
0.775\end{array}$ \\
\hline \multirow[t]{3}{*}{$\begin{array}{l}\text { IL-6 } \\
-596 \mathrm{G}>\mathrm{A} \\
\mathrm{rs} 1800797 \\
\end{array}$} & GG & $11(14.2)$ & $11(11.5)$ & $0.308^{\mathrm{a}}$ & - & $4(5.3)$ & $3(5.5)$ & $0.881^{\mathrm{a}}$ & - \\
\hline & GA & $28(21.6)$ & $24(23)$ & & $\begin{array}{c}0.857 \\
(0.281-2.623) \\
0.960\end{array}$ & $11(8.4)$ & $16(11)$ & & $\begin{array}{c}1.939 \\
(0.263-15.67) \\
0.720\end{array}$ \\
\hline & $\mathrm{AA}$ & $5(8.2)$ & $11(11.5)$ & & $\begin{array}{c}2.2 \\
(0.48-10.78) \\
0.412\end{array}$ & $2(3.3)$ & $3(5.5)$ & & $\begin{array}{c}2.000 \\
(0.121-37.87) \\
1.000\end{array}$ \\
\hline HWE $p$ & & 0.049 & 0.768 & & & 0.198 & 0.033 & & \\
\hline Allele G & & 50 & 46 & $0.359^{\mathrm{a}}$ & Reference & 19 & 22 & $0.606^{\mathrm{a}}$ & Reference \\
\hline Allele A & & 38 & 46 & & $\begin{array}{c}1.316 \\
(0.702-2.470) \\
0.443\end{array}$ & 15 & 22 & & $\begin{array}{c}1.267 \\
(0.470-3.428) \\
0.775\end{array}$ \\
\hline \multirow{3}{*}{$\begin{array}{l}\text { TNF- } \alpha \\
-308 \mathrm{G}>\mathrm{A} \\
\mathrm{rs} 1800629\end{array}$} & GG & $31(32)$ & $36(36.5)$ & $0.472^{\mathrm{a}}$ & - & $12(12.4)$ & 15 (15.6) & $1.000^{\mathrm{a}}$ & - \\
\hline & GA & $13(11.1)$ & $10(9)$ & & $\begin{array}{c}0.662 \\
(0.226-1.906) \\
0.544\end{array}$ & $5(4.2)$ & $7(5.9)$ & & $\begin{array}{c}1.12 \\
(0.233-5.699) \\
1.000\end{array}$ \\
\hline & AA & $0(0.9)$ & $0(0.5)$ & & - & $0(0.4)$ & $0(0.5)$ & & - \\
\hline HWE $p$ & & 0.250 & 0.408 & & & 0.477 & 0.375 & & \\
\hline Allele G & & 75 & 82 & $0.433^{\mathrm{a}}$ & Reference & 29 & 37 & $0.865^{\mathrm{c}}$ & Reference \\
\hline Allele A & & 13 & 10 & & $\begin{array}{c}0.704 \\
(0.260-1.858) \\
0.572\end{array}$ & 5 & 7 & & $\begin{array}{c}1.097 \\
(0.267-4.860) \\
1.000\end{array}$ \\
\hline
\end{tabular}

$\overline{{ }^{a} \chi^{2},{ }^{b} \text { Fisher-Freeman-Halton, }{ }^{c} \chi^{2}}$

Our most important finding from the analysis of the occurrence of studied polymorphisms was that IL-1 receptor antagonist genotype distribution differs significantly among the patients with ROP who did not require treatment and those in whom treatment was necessary. IL-1 receptor antagonist is a competitive inhibitor of IL-1-induced pro-inflammatory activity. Its encoding gene is polymorphic, resulting in quantitative differences in production of both IL-1 receptor antagonist and IL-1 $\beta$ [31]. The VNTR polymorphism occurs within intron 2 of the human $I L-1 R N$ gene and consists of repeats of an 86-bp sequence. The number of repeats is of functional significance because these repeats contain binding sites for transcription factors [32]. In our study, the $I L-1 R N$ VNTR polymorphism was distributed with a higher proportion of rare 2/2 genotype in the group of patients who required treatment. Conversely, a more frequent occurrence of major 1/1 genotype was found in patients with ROP that regressed spontaneously. Interestingly, the $2 / 2$ genotype was also found in the only infant from our study group who required retreatment due to ROP recurrence. This would suggest the possible connection between the $2 / 2$ genotype and a more severe course of ROP. This finding is in accordance with the study of Witkin [31], who reported that prolonged and more intense pro-inflammatory response is observed in homozygote IL1-RN gene 2 allele (IL1-RN*2). Similar to Dammann et al. [16], we also found that genetic markers, in our case $I L-1 R N$ VNTR polymorphism, were not associated with ROP occurrence, but with progression to the high-grade disease. This may be an indication that already susceptible 
infants' may possess a genetic predisposition that makes them vulnerable to infection and subsequently puts them at even greater risk of progression of ROP.

The analysis revealed also that there was a higher proportion of the $2 / 2 \mathrm{IL}-1 \mathrm{RN}$ genotype in patients with ROP and intrauterine infection compared to ROP patients without intrauterine infection. This finding requires further research in a larger study group.

We also analysed $I L-1 \beta+3953 \mathrm{C}>\mathrm{T}$ and $T N F-\alpha-308$ $\mathrm{G}>\mathrm{A}$ gene polymorphisms due to the pro-inflammatory properties of IL- 1 and TNF- $\alpha$ cytokines. Previous studies evaluating IL-1 $\beta$ and TNF- $\alpha$ plasma levels observed inconsistent results on whether they are involved in the development of proliferative retinopathies. Mysliwiec et al. [33], Gardner et al. [34], and Meleth et al. [35] reported elevated levels of IL-1 $\beta$ and TNF- $\alpha$ in diabetic retinopathy. Conversely, the large population-based study of Sood et al. [28] did not find these cytokines to be significantly associated with ROP severity. The genetic exploratory analyses of Dammann et al. [16] suggest a trend toward protection in occurrence, but a risk increase in ROP progression with the presence of $I L-1 \beta$ and $T N F-\alpha$ SNPs. Similar to Türe $e t$ al. [36], our study showed no correlation between $T N F-\alpha$ $-308 \mathrm{G}>\mathrm{A}$ gene polymorphisms and susceptibility to ROP. Also, as in the study by Cook et al. [37], there was no significant difference for $T N F-\alpha-308 \mathrm{G}>\mathrm{A}$ polymorphism distribution between preterm infants who received treatment for threshold ROP and infants who did not. Neither did our data demonstrate any predictive value for the $I L$ $1 \beta+3953 \mathrm{C}>\mathrm{T}$ polymorphism increasing the risk of ROP development/progression in preterm infants.

To date there have been no studies assessing the link between $I L-6-174 \mathrm{G}>\mathrm{C}$ and $I L-6-596 \mathrm{G}>\mathrm{A}$ polymorphism and ROP. Previous research indicates only that in preterm infants, development of ROP was associated with elevated levels of IL-6 [28]. The replacement of guanine with cytosine at position -174 of the $I L-6$ gene results in diminished production of IL6 in homozygous CC individuals. Similarly, the replacement of guanine by adenosine at position -596 causes decreased IL- 6 production by AA homozygotes. Our analysis did not find an association between either the $I L-6-174 \mathrm{G}>\mathrm{C}$ or the $I L-6-596$ $\mathrm{G}>\mathrm{A}$ polymorphism genotypes and ROP; this has not been reported previously. However, we observed a significant deviation from Hardy-Weinberg equilibrium for both IL-6 polymorphisms for ROP patients, for ROP patients with intrauterine infection, and for the patients without intrauterine infection; the deviation was also present for $I L-6$ $-596 \mathrm{G}>\mathrm{A}$ polymorphism for ROP patients not requiring treatment, which might indicate the association of these polymorphisms with the occurrence of disease. This finding requires further research in a larger study group.

The limitations of our study include the relatively small sample size, which did not allow for further statistical analyses, and the lack of measurement of plasma levels of IL-1, IL-6, TNF- $\alpha$, and IL-1RA cytokines, which precludes the possibility of relating specific polymorphisms and their expression in studied patients. Thus, our study demonstrates preliminary results, which should be confirmed by further research.

\section{Conclusions}

The results of our study support the idea that retinopathy of prematurity is a multifactorial disease in which environmental (e.g. BW, GA, mechanical ventilation) and genetic risk factors (genotype $2 / 2 I L-1 R N$ ) interact. Future investigations of polymorphisms in inflammation-associated genes, especially in $I L-1 R N$ VNTR $86 \mathrm{bp}$, may provide valuable insight into the pathogenic mechanisms underlying the development of ROP and help to identify the most susceptible infants and treat ROP even more effectively.

\section{The authors declare no conflict of interest.}

\section{References}

1. Gilbert C (2008): Retinopathy of prematurity: A global perspective of the epidemics, population of babies at risk and implications for control. Early Hum Dev 84: 77-82.

2. Kong L, Fry M, Al-Samarraie M, et al. (2012): An update on progress and the changing epidemiology of causes of childhood blindness worldwide. J AAPOS 16: 501-507.

3. Isaza G, Arora S, Bal M, Chaudhary V (2013): Incidence of Retinopathy of Prematurity and Risk Factors Among Premature Infants at a Neonatal Intensive Care Unit in Canada. J Pediatr Ophthalmol Strabismus 50: 27-32.

4. Chen Y-H, Lien R-I, Tsai S, et al. (2015): Natural history of retinopathy of prematurity: two-year outcomes of a prospective study. Retina 35: 141-148.

5. Mathew MRK, Fern AI, Hill R (2002): Retinopathy of prematurity: are we screening too many babies? Eye (Lond) 16: 538-542.

6. Klufas MA, Patel SN, Ryan MC, et al. (2015): Influence of Fluorescein Angiography on the Diagnosis and Management of Retinopathy of Prematurity. Ophthalmology 122: 1601-1608.

7. Palmer EA (1990): Results of U.S. randomized clinical trial of cryotherapy for ROP (CRYO-ROP). Doc Ophthalmol 74: 245-251.

8. Reynolds JD, Dobson V, Quinn GE, et al. (2002): Evidence-based screening criteria for retinopathy of prematurity: natural history data from the CRYO-ROP and LIGHT-ROP studies. Arch Ophthalmol 120: 1470-1476.

9. Early Treatment For Retinopathy Of Prematurity Cooperative Group (2003): Revised indications for the treatment of retinopathy of prematurity: results of the early treatment for retinopathy of prematurity randomized trial. Arch Ophthalmol 121: 1684-1694.

10. Chen ML, Guo L, Smith LEH, et al. (2010): High or low oxygen saturation and severe retinopathy of prematurity: a meta-analysis. Pediatrics 125: e1483-1492.

11. Manzoni P, Farina D, Maestri A, et al. (2007): Mode of delivery and threshold retinopathy of prematurity in pre-term ELBW neonates. Acta Paediatr 96: 221-226. 
12. Mohamed S, Murray JC, Dagle JM, et al. (2013): Hyperglycemia as a risk factor for the development of retinopathy of prematurity. BMC Pediatr 13: 78.

13. Port AD, Chan RVP, Ostmo S, et al. (2014): Risk factors for retinopathy of prematurity: insights from outlier infants. Graefes Arch Clin Exp Ophthalmol 252: 1669-1677.

14. Alajbegovic-Halimic J, Zvizdic D, Alimanovic-Halilovic E, et al. (2015): Risk Factors for Retinopathy of Prematurity in Premature Born Children. Med Arch 69: 409-413.

15. Chen J, Smith LEH (2007): Retinopathy of prematurity. Angiogenesis 10: 133-140.

16. Dammann O, Brinkhaus M-J, Bartels DB, et al. (2009): Immaturity, perinatal inflammation, and retinopathy of prematurity: a multi-hit hypothesis. Early Hum Dev 85: 325-329.

17. Lee J, Dammann O (2012): Perinatal infection, inflammation, and retinopathy of prematurity. Semin Fetal Neonatal Med 17: 32-35.

18. Wilson CM, Ells AL, Fielder AR (2013): The challenge of screening for retinopathy of prematurity. Clin Perinatol 40: 241-259.

19. International Committee for the Classification of Retinopathy of Prematurity (2005): The International Classification of Retinopathy of Prematurity Revisited. Arch Ophthalmol 123: 991.

20. Fierson WM, American Academy of Pediatrics Section on Ophthalmology, American Academy of Ophthalmology, et al. (2013): Screening examination of premature infants for retinopathy of prematurity. Pediatrics 131: 189-195.

21. Mintz-Hittner HA, Kennedy KA, Chuang AZ, BEAT-ROP Cooperative Group (2011): Efficacy of intravitreal bevacizumab for stage 3+ retinopathy of prematurity. N Engl J Med 364: 603-615.

22. Lamont RF (2003): Infection in the prediction and antibiotics in the prevention of spontaneous preterm labour and preterm birth. BJOG An Int J Obstet Gynaecol 110: 71-75.

23. Wheatley CM, Dickinson JL, Mackey DA, et al. (2002): Retinopathy of prematurity: recent advances in our understanding. Br J Ophthalmol 86: 696-700.

24. Mohamed S, Schaa K, Cooper ME, et al. (2009): Genetic contributions to the development of retinopathy of prematurity. Pediatr Res 65: 193-197.

25. Silveira RC, Filho JBF, Procianoy RS, et al. (2011): Assessment of the Contribution of Cytokine Plasma Levels to Detect Retinopathy of Prematurity in Very Low Birth Weight Infants. Investig Opthalmology Vis Sci 52: 1297. 